\title{
Partitioning Behavior of Papain in Ionic Liquids-Based Aqueous Two-Phase Systems
}

\author{
Zhiwen Bai, ${ }^{1,2}$ Yanhong Chao, ${ }^{2}$ Meiling Zhang, ${ }^{2}$ Changri Han,, Wenshuai Zhu, \\ Yonghui Chang, ${ }^{1}$ Huaming $\mathrm{Li}^{2}{ }^{2}$ and Yang Sun ${ }^{2}$ \\ ${ }^{1}$ Key Laboratory of Tropical Medicinal Plant Chemistry of Education, Hainan Normal University, \\ Haikou 571158, China \\ ${ }^{2}$ College of Chemistry and Chemical Engineering, Jiangsu University, Xuefu Road 301, Zhenjiang 212013, China \\ Correspondence should be addressed to Yanhong Chao; chaoyh@ujs.edu.cn and Changri Han; hchr116@126.com
}

Received 30 May 2013; Revised 15 August 2013; Accepted 18 August 2013

Academic Editor: M. Natália D. S. Cordeiro

Copyright (C) 2013 Zhiwen Bai et al. This is an open access article distributed under the Creative Commons Attribution License, which permits unrestricted use, distribution, and reproduction in any medium, provided the original work is properly cited.

\begin{abstract}
This paper attempts to study and optimize the affinity partitioning conditions of papain in an aqueous two-phase system (ATPS). The effect of the amount of ionic liquids (ILs), the concentration of $\mathrm{K}_{2} \mathrm{HPO}_{4}$, temperature, $\mathrm{pH}$, and the volume of papain solution were discussed concretely. The optimum conditions were determined as ionic liquid was $1.4 \mathrm{~g}$ and $\mathrm{K}_{2} \mathrm{HPO}_{4}$ was $1.4 \mathrm{~g}$, the extraction efficiency of papain could reach $98.33 \%$ with $\mathrm{pH}$ unadjusted. The temperature and the $\mathrm{pH}$ of the solution are major parameters that influence the partitioning of protein in ILs-based ATPSs. The partition of papain to the IL-rich phase was enhanced by increasing the amount of ILs, the concentration of $\mathrm{K}_{2} \mathrm{HPO}_{4}$, and temperature, especially at its isoelectric point.
\end{abstract}

\section{Introduction}

Papain (EC3.4.22.2) is an endolytic cysteine protease obtained from the latex of papaya (Carica papaya), which can catalyze hydrolysis of peptide bonds of basic amino acids, such as leucine or glycine [1]. As one of the most widely used industrial enzymes, papain has been used in medical application, cell isolation, detergents, leather, textiles, cosmetic, food, and pharmaceutical industries [2-4]. Several studies have been reported for papain extraction by classical ATPSs method [5-7]. The main problems of these polymer-based ATPSs are high viscosity of the polymer and the difficulty to isolate the extracted molecules from the polymer phase by back extraction.

Aqueous two-phase systems (ATPSs) are usually formed as a result of mutual incompatibility of two polymers or one polymer and one salt above a certain concentration. Since the bulk of both phases comprises water [8], ATPSs have advantages over the conventional extraction systems using organic solvents such as short processing time, low energy consumption, relative reliability in scale-up, and a biocompatible environment [9-11]. They provide an economical, efficient downstream-processing method and have been demonstrated for the successful usage for recovery and purification of many biological materials such as proteins, enzymes, and nucleic acids [12-14].

In recent years, ionic liquids-(ILs-) based ATPSs as a new type of green system have shown many advantages in separation and purification, such as system which is easy to zoom in, faster mass transfer and balance, high extraction efficiency, low viscosity, little emulsion formation, no need of using volatile organic solvent, and gentle biocompatible environment. Therefore, these novel ATPSs have been successfully used to separate proteins, amino acids, alkaloids, and saccharides among others [13, 15-22].

In this paper, papain has been selected as model protein. The partitioning behavior of these proteins in the aqueous two-phase systems of $[\mathrm{Bmim}] \mathrm{X}(\mathrm{X}=\mathrm{Cl}, \mathrm{Br})+\mathrm{K}_{2} \mathrm{HPO}_{4}$ has been studied. Factors affecting the partitioning of the proteins were investigated in detail, such as the composition of the two-phase systems, the $\mathrm{pH}$ value, and the temperature of the systems. The results have been discussed from the interactions between the proteins and the ionic liquids in the aqueous two-phase systems. 


\section{Experimental}

2.1. Materials. [Bmim]X $(\mathrm{X}=\mathrm{Cl}, \mathrm{Br})$ was purchased from Cheng jie Chemical Co., Ltd. (Shanghai, China), with a quoted purity of greater 0.99 mass fraction. The standard sample of proteins was obtained from the Chinese National Institute for the Control of Pharmaceutical and Biological Products (Beijing, China). All other chemicals were of analytical grade and were used as received. The stock solution of proteins was prepared at a concentration of $10.0 \mathrm{mg} \cdot \mathrm{mL}^{-1}$ and stored at $4^{\circ} \mathrm{C}$ in a refrigerator. Standard working solutions of proteins were prepared by appropriately diluting the stock solution. All the solutions were prepared using deionized water throughout the entire experiments.

\subsection{Preparation of Phase Diagram for $I L+$ Salt Aqueous Two-} Phase Systems. The binodal curves of the aqueous two-phase systems were determined by the cloud-point method [23]. In a test tube, a few grams of concentrated IL solution were weighed in. The glass tube was immersed in a jacketed glass vessel, and the temperature of the system was maintained at constant temperature within $\pm 0.05 \mathrm{~K}$ by a DC-2006 water thermostat (Jiangsu Jintan Instrument Factory, China). A solution of known concentration of a salt was added dropwise until the mixture became turbid or cloudy; then a known mass of water was added to make the mixture clear again. This procedure was repeated to obtain sufficient data for the construction of a liquid-liquid equilibrium binodal curve.

2.3. Aqueous Two-Phase Extraction. Aqueous two-phase extraction experiments were implemented by mixing a special amount of ILs, $\mathrm{K}_{2} \mathrm{HPO}_{4}$ and the solution of protein in $10 \mathrm{~mL}$ graduated tubes. The tested concentration of protein was $10.0 \mathrm{mg} \cdot \mathrm{mL}^{-1}$. The mixture was gently stirred for $30 \mathrm{~min}$ to attain equilibrium. After plenary mixing, the mixture was centrifuged at 4,000 rpm for $10 \mathrm{~min}$ and then placed into a thermostatic water bath at $25 \pm 0.05^{\circ} \mathrm{C}$ for $0.5 \mathrm{~h}$ to reach thorough phase separation. The volume of top and bottom phases was recorded. The sample was then collected from the IL-rich phase and diluted for analysis. The samples were diluted and analyzed against blanks containing the same phase composition but without protein to avoid interference from phase components.

The $\mathrm{pH}$ values of phosphate solution were measured with a 720 Orion $\mathrm{pH}$ meter using a combination $\mathrm{pH}$ electrode by adding the aqueous solution of $\mathrm{KOH}$ or $\mathrm{H}_{3} \mathrm{PO}_{4}$.

2.4. Determination of Protein Concentration in Aqueous TwoPhase Systems. The protein concentrations in aqueous twophase systems were determined by measuring the absorbance at $275 \mathrm{~nm}$ for papain by using a UV-2401PC UV-vis spectrophotometer (Beijing Purkinje General Instrument Company, Ltd., Beijing, China). The partitions of proteins between the two phases were characterized by partition coefficients $(K)$, phase volume ratio $(R)$, and extraction efficiency $(E)$.
The partitioning parameters were calculated by the following equations:

$$
\begin{gathered}
K=\frac{C_{t}}{C_{b}}, \\
R=\frac{V_{t}}{V_{b}}, \\
E=\frac{C_{t} V_{t}}{C_{t} V_{t}+C_{b} V_{b}}=\frac{K R}{1+K R},
\end{gathered}
$$

where $C_{t}$ and $C_{b}$ are the equilibrium concentrations of the partitioned proteins in the top IL-rich phase and the bottom salt-rich phase, respectively. $V_{t}$ and $V_{b}$ stand for the volumes of the top phase and the bottom phase.

2.5. UV-Vis and FT-IR Spectra to Study the Interaction between Protein and Ionic Liquids. The UV and FT-IR spectra of papain in $[\mathrm{Bmim}] \mathrm{Br} / \mathrm{K}_{2} \mathrm{HPO}_{4}$ system were studied for the protein conformation. In each experiment, the top IL-rich phase containing papain was collected to measure the UV-vis spectra on a UV-2401PC UV-vis spectrophotometer (Beijing Purkinje General Instrument Company, Ltd., Beijing, China). The blanks which contained the same phase composition but without papain were used as reference solution. FT-IR spectra were recorded by using a Thermo Nicolet Nexus 470 IR spectrophotometer with a resolution of $2 \mathrm{~cm}^{-1}$. A simulation system containing papain, $[\mathrm{Bmim}] \mathrm{Br}$, and water was employed to investigate the FT-IR spectra. The spectrum of papain in [Bmim] Br was measured by compounding $2 \mathrm{mg}$ of papain, $2 \mathrm{mg}$ of moisture [Bmim] Br with $200 \mathrm{mg} \mathrm{KBr}$ as a pellet pressed with a $\mathrm{KBr}$ pellet. The spectra of pure papain and $[\mathrm{Bmim}] \mathrm{Br}$ were also collected using $\mathrm{KBr}$ pellet method.

\section{Results and Discussion}

3.1. Phase Diagram of ATPSs. Binodal curves of the ILs + $\mathrm{K}_{2} \mathrm{HPO}_{4}$ systems have been determined through the cloudpoint titration method [23]. The top phase is IL rich while the bottom phase is phosphate rich. Three pieces of information could be concluded, such as the concentration of phase-forming components required to form two phases, the concentration of phase components in the top and bottom phases, and the ratio of phase volumes. It is known that the closer to the origin of the binodal curve, the lower the IL concentration formed two phases and then the stronger the phase-forming ability of the IL was. The result shown in Table 1 was in accordance with the reported literature [24].

3.2. Effect of the Amount of [Bmim] X $(\mathrm{X}=\mathrm{Cl}, \mathrm{Br})$ and $\mathrm{K}_{2} \mathrm{HPO}_{4}$ on the Partition Behavior of Papain. The extraction efficiency of papain in [Bmim]X $(\mathrm{X}=\mathrm{Cl}, \mathrm{Br})-\mathrm{K}_{2} \mathrm{HPO}_{4}$ ILATPS at different amounts of ILs and $\mathrm{K}_{2} \mathrm{HPO}_{4}$ was listed in Figures 1 and 2. In Figure 1, different amounts of ILs were added to $1.3 \mathrm{~mL}$ papain solutions containing different amount of $\mathrm{K}_{2} \mathrm{HPO}_{4}$. When the amount of ILs was $0.4 \mathrm{~g}$, the minimal amount of $\mathrm{K}_{2} \mathrm{HPO}_{4}$ which can form ATPS was $0.6 \mathrm{~g}$.

The extraction efficiency of papain was influenced by the combined impacts of the amount of IL and the concentration 
TABLE 1: The phase compositions of ILs (1) $+\mathrm{K}_{2} \mathrm{HPO}_{4}$ and (2) ATPSs at $T=298.15 \mathrm{~K}$

\begin{tabular}{lccc}
\hline \multicolumn{2}{c}{$[\mathrm{Bmim}] \mathrm{Cl}+\mathrm{K}_{2} \mathrm{HPO}_{4}$} & \multicolumn{2}{c}{$[\mathrm{Bmim}] \mathrm{Br}+\mathrm{K}_{2} \mathrm{HPO}_{4}$} \\
$w_{1}$ & $w_{2}$ & $w_{1}$ & $w_{2}$ \\
\hline 0.0156 & 0.4823 & 0.0384 & 0.4522 \\
0.0255 & 0.4357 & 0.0522 & 0.4013 \\
0.0416 & 0.4013 & 0.0738 & 0.3478 \\
0.0834 & 0.3119 & 0.0912 & 0.3047 \\
0.1208 & 0.2498 & 0.1174 & 0.2504 \\
0.1637 & 0.1818 & 0.1553 & 0.1921 \\
0.2011 & 0.1450 & 0.1767 & 0.1588 \\
0.2413 & 0.1115 & 0.1921 & 0.1446 \\
0.2527 & 0.1006 & 0.2257 & 0.1125 \\
0.2659 & 0.0857 & 0.2328 & 0.1062 \\
0.2866 & 0.0774 & 0.2457 & 0.0901 \\
0.3057 & 0.0652 & 0.2632 & 0.0788 \\
0.3284 & 0.0589 & 0.2809 & 0.0632 \\
0.4021 & 0.0421 & 0.2952 & 0.0516 \\
0.4351 & 0.0368 & 0.3156 & 0.0481 \\
\hline
\end{tabular}

of $\mathrm{K}_{2} \mathrm{HPO}_{4}$. When the amount of [Bmim]Br was $0.4 \mathrm{~g}$ and the $\mathrm{K}_{2} \mathrm{HPO}_{4}$ was $0.6 \mathrm{~g}$, the extraction efficiency of papain was about 90.59\%; however, when the mass of [Bmim] Br was $1.4 \mathrm{~g}$ and the concentration of $\mathrm{K}_{2} \mathrm{HPO}_{4}$ was $1.4 \mathrm{~g}$, the extraction efficiency of papain has already reached $98.33 \%$.

As shown in Figure 1, when the concentration of $\mathrm{K}_{2} \mathrm{HPO}_{4}$ was a fixed value, the extraction efficiency of papain increased with the increasing amount of $[\mathrm{Bmim}] \mathrm{Br}$. The hydration between salt ions and water molecules leads to the phaseforming salt dissolving in the bottom phase. Meanwhile, the amount of free water molecules in the bottom phase reduces, and it results in the exclusion of ILs and target. The amount of water molecules in the ILs-rich phase rose with the increase of the amount of ILs, and due, to the good water solubility of papain, the amount of papain which can transfer to the top phase also increased.

Figure 2(a) showed the influence of the concentration of $\mathrm{K}_{2} \mathrm{HPO}_{4}$ on the extraction efficiency of papain when the amount of $[\mathrm{Bmim}] \mathrm{Cl}$ was $0.6 \mathrm{~g}$. The extraction efficiency of papain achieved the maximum value $(97.64 \%)$ when the amount of $\mathrm{K}_{2} \mathrm{HPO}_{4}$ was $1.2 \mathrm{~g}$. Then with the growth in the concentration of $\mathrm{K}_{2} \mathrm{HPO}_{4}$, the extraction efficiency slightly decreased. The phase volume ratio of the system decreased with the growth in the concentration of $\mathrm{K}_{2} \mathrm{HPO}_{4}$. Similarly, from Figure 1, when the volume of $[\mathrm{Bmim}] \mathrm{Br}$ was $0.4 \mathrm{~g}$ or $0.6 \mathrm{~g}$, the extraction efficiency of papain was obviously the same trend. When the salt solution reached equilibrium concentration in the bottom phase, redundant salt will transfer to the top phase as salt concentration increased. The salt dissolving in the top phase combined with water molecules through hydration, so the amount of free water molecules in the top phase reduced, leading to a small part of papain retransferring to the bottom phase. Therefore, high concentration of salt was not conducive to the extraction of the target. For instance, in Figure 2(b), when the amount of $\mathrm{K}_{2} \mathrm{HPO}_{4}$ was fixed, the extraction efficiency of papain

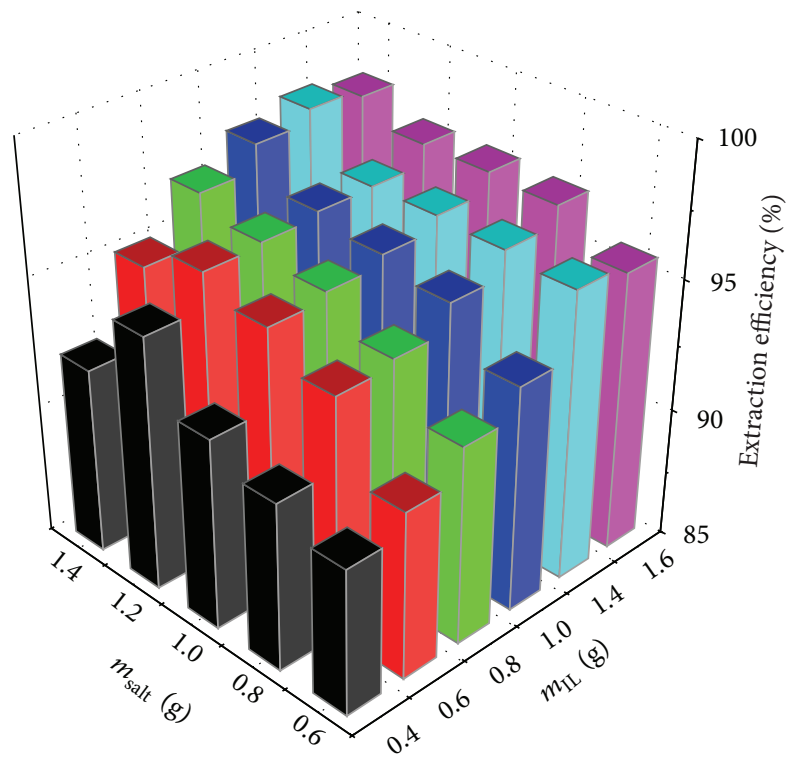

FIGURE 1: The influence of the amount of [Bmim]Br on the extraction efficiency $(E \%)$ of papain at different concentrations of $\mathrm{K}_{2} \mathrm{HPO}_{4}$.

improved with the amount of ILs added. From Figures 1 and 2 , when the concentration of $\mathrm{K}_{2} \mathrm{HPO}_{4}$ was a fixed value and the amount of [Bmim] Br was from $0.4 \mathrm{~g}$ to $1.6 \mathrm{~g}$, the extraction efficiency of papain obviously increased, especially when the dosage of [ $\mathrm{Bmim}] \mathrm{Br}$ was from $0.4 \mathrm{~g}$ to $0.6 \mathrm{~g}$.

3.3. Effect of $p H$ on the Partition Coefficients. It is known that $\mathrm{pH}$ is a major parameter to influence the partitioning of protein in ILs-based ATPSs. Because IL-phosphate systems cannot form aqueous two phases at $\mathrm{pH}$ below 6.0, protein denaturation and conformational change always occurs at extreme $\mathrm{pH}$ values. So an attempt has been made to determine partition coefficients of papain in the $\mathrm{pH}$ range from 7.0 to 12.0, and the result is shown in Figure 3. It can be seen that partition coefficients of the papain are quite high and maximize at the $\mathrm{pH}$ value close to its isoelectric point $(\mathrm{pI}=8.75)$. There was a decrease of the extraction efficiency below and above the isoelectric point of the protein. It is known that, at the isoelectric point, proteins carry net positive and negative charges equally and have minimum solubility in water. Therefore, the maximum extraction efficiency of papain should be expected when the solution $\mathrm{pH}$ is at or close to its $\mathrm{pI}$ value. It indicated that electrostatic interactions between the charged groups in the protein and the ionic group of the ionic liquids played an important role in determining the dependence of extraction efficiency of papain on the $\mathrm{pH}$ values of aqueous solutions.

As known there are aromatic residues such as Tyr and Phe, which exist on the surface of the proteins and constitute approximately $10 \%$ of the total residues [25]. Imidazolium cation of the ILs has an aromatic $\pi$ system. It appears that electro-richer aromatic $\pi$ system on the cationic moiety of the ILs produces stronger interactions with protein molecules capable of undergoing $\pi-\pi$ interactions. Thus, the $\pi-\pi$ stacking interaction between the imidazolium cation and the 


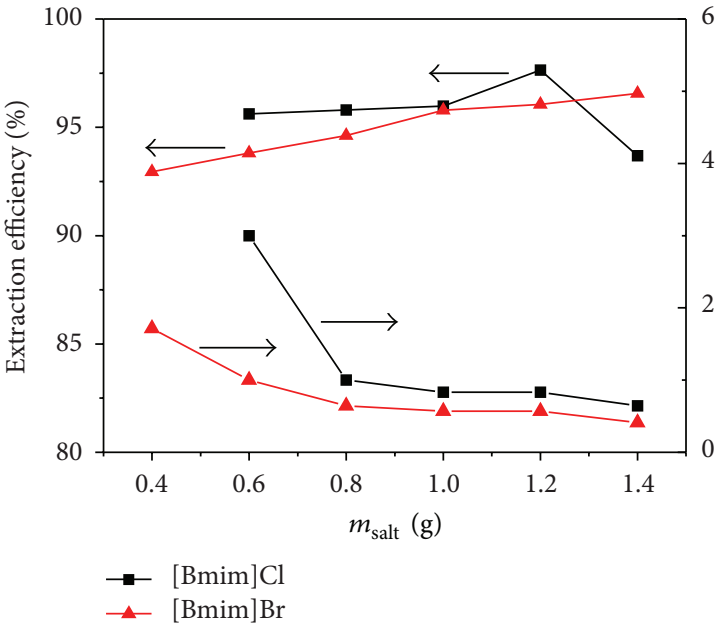

(a)
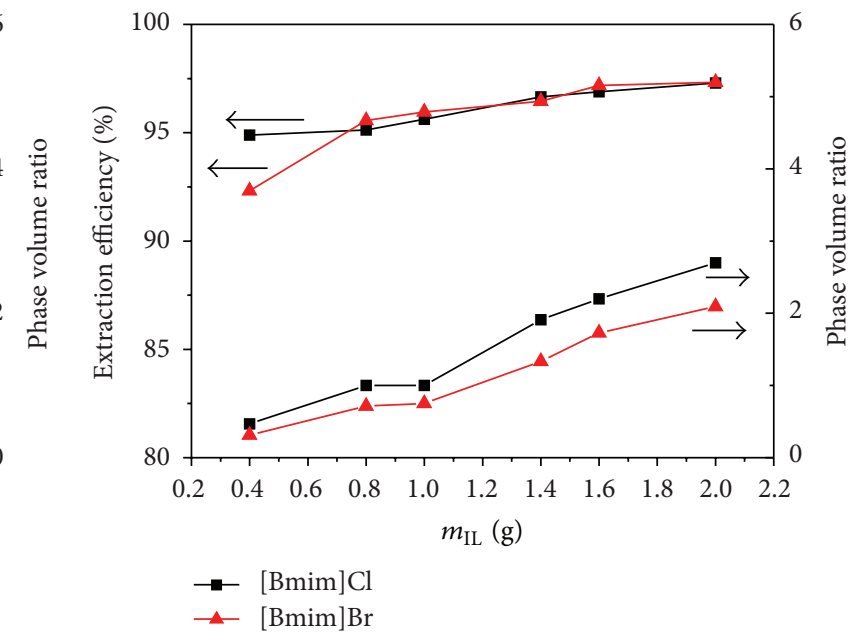

(b)

FIGURE 2: (a) The influence of the amount of $\mathrm{K}_{2} \mathrm{HPO}_{4}$ on the extraction efficiency of papain; (b) the influence of the amount of ILs on the extraction efficiency of papain.

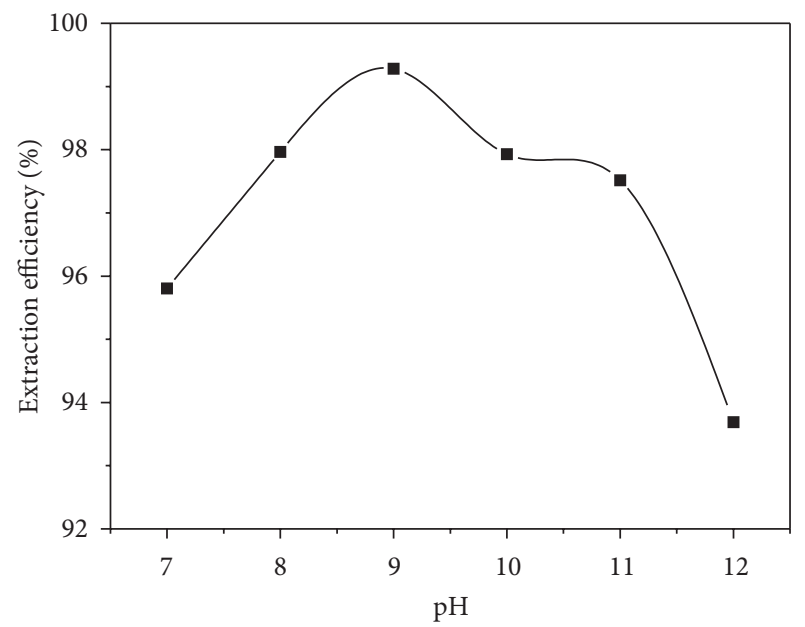

Figure 3: Effect of $\mathrm{pH}$ on the extraction efficiency of papain in $[\mathrm{Bmim}] \mathrm{Cl}+\mathrm{K}_{2} \mathrm{HPO}_{4}$ aqueous two-phase systems at $25^{\circ} \mathrm{C}$.

aromatic residues of the proteins is a possible driving force for the partition of proteins.

3.4. Effect of Temperature on Partitioning of the Protein. Temperature is another important factor for the partition of proteins in the aqueous two-phase systems. The influence of temperature on the extraction efficiency of papain was discussed from $25^{\circ} \mathrm{C}$ to $65^{\circ} \mathrm{C}$ when the amount of ILs was $0.6 \mathrm{~g}$ and $\mathrm{K}_{2} \mathrm{HPO}_{4}$ was $0.8 \mathrm{~g}$. As can be seen from the Figure 4 , the partition coefficients of papain in ILs-ATPSs was studied. The result showed that the partition coefficients increased with the increasing temperature. The volumes ratio of the ATPS always enlarged as the temperature rose, and it meant that more and more water molecules were transferred to the top phase. This result implied that the higher temperature favored the protein extraction, and the partitioning of proteins was an endothermic process.

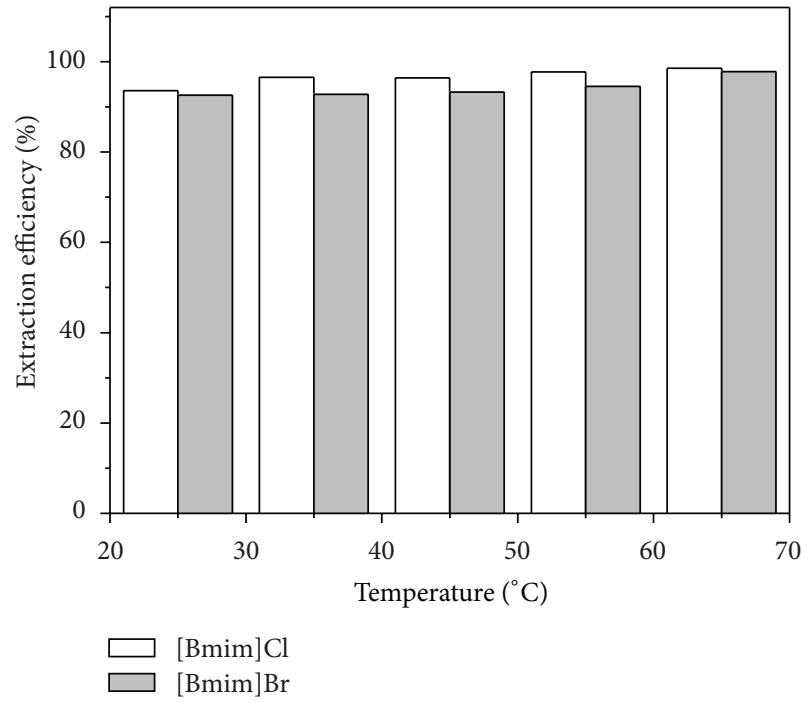

FIGURE 4: Effect of temperature on the partition coefficients of papain in the ILs $+\mathrm{K}_{2} \mathrm{HPO}_{4}$ aqueous two-phase systems $(0.8 \mathrm{~g}$ $\mathrm{K}_{2} \mathrm{HPO}_{4}+0.6 \mathrm{~g} \mathrm{ILs}+1.3 \mathrm{~mL} \mathrm{H} \mathrm{H}_{2} \mathrm{O}$.

3.5. Effect of Volume of Protein on the Partition Coefficients. At the $\mathrm{pH}$ without adjusting, the influence of the volume of papain solution on the extraction efficiency was discussed from $0.9 \mathrm{~mL}$ to $1.9 \mathrm{~mL}$ when the amount of ILs was $0.6 \mathrm{~g}$ and $\mathrm{K}_{2} \mathrm{HPO}_{4}$ was $0.8 \mathrm{~g}$. As can be seen from Figure 5, the partition coefficients of papain decrease with increasing the volume of protein solution in the ionic liquids ATPSs. [Bmim] Cl with $\mathrm{K}_{2} \mathrm{HPO}_{4}$ system absolutely decreased with increasing the volume of protein solution, but the partition coefficients of the [Bmim] Br with $\mathrm{K}_{2} \mathrm{HPO}_{4}$ system increased with the volume of protein solution from $0.9 \mathrm{~mL}$ to $1.1 \mathrm{~mL}$ and then decreased with increasing the volume of protein solution. So it indicated that high volume of protein solution was not conducive to the extraction of the target. 


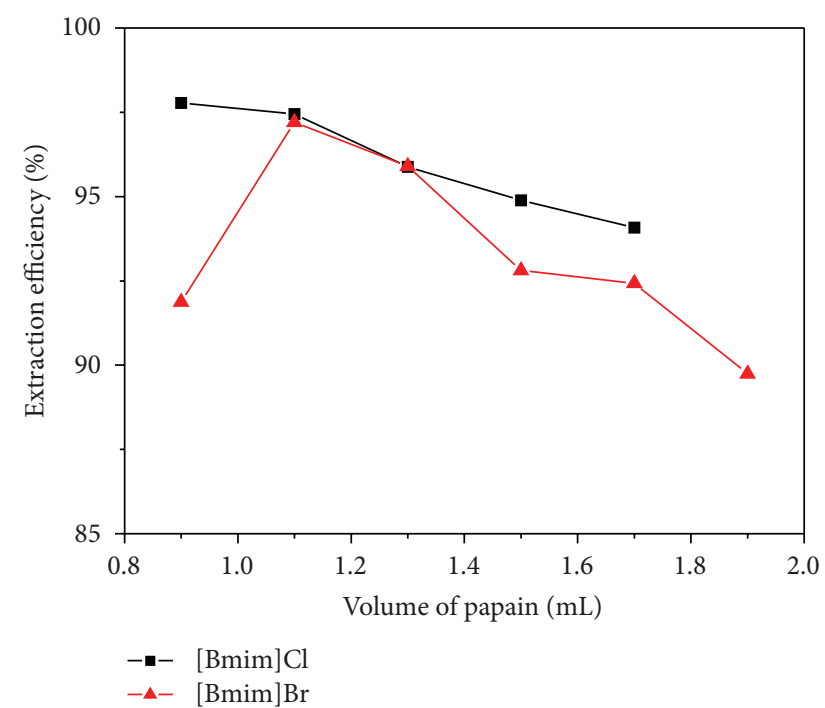

FIGURE 5: Effect of volume of protein on the partition coefficients in the ILs $+\mathrm{K}_{2} \mathrm{HPO}_{4}$ aqueous two-phase systems $\left(0.8 \mathrm{~g} \mathrm{~K}_{2} \mathrm{HPO}_{4}\right.$ $+0.6 \mathrm{~g} \mathrm{ILs}+1.3 \mathrm{~mL} \mathrm{H}_{2} \mathrm{O}$ ).

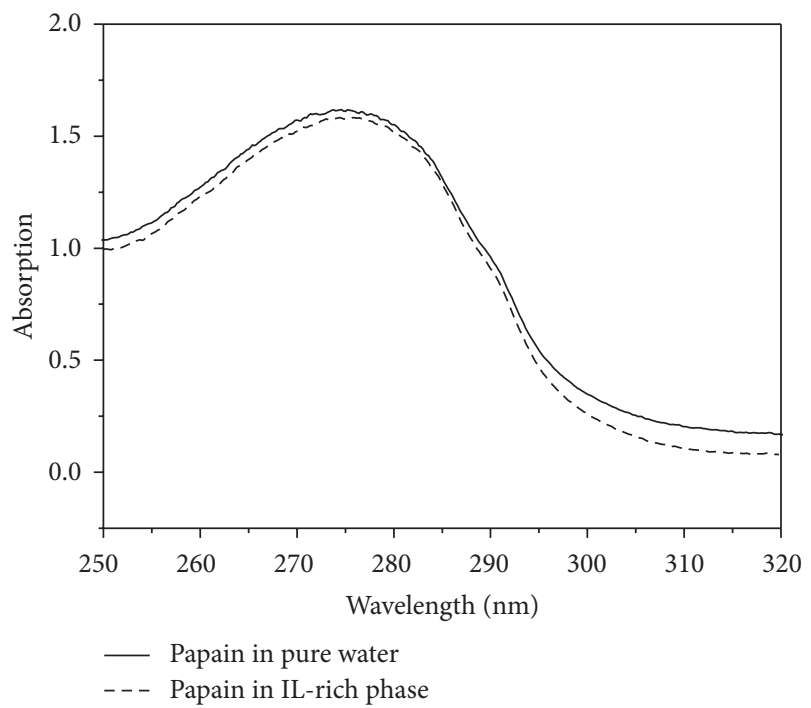

FIGURE 6: UV spectra of papain in pure water and in [Bmim]Br-rich upper phase.

3.6. Examination of the Proteins Conformation before and after Extraction. In order to examine the proteins conformation before and after extraction, UV and FT-IR spectra of papain were investigated. Figure 6 shows the UV spectra of papain in pure water and in [Bmim] Br-rich upper phase after extraction. It is clear that the UV spectra of papain is similar, and its maximal absorption is at the same position (at $275 \mathrm{~nm}$ ) in two different media, suggesting that there are no chemical interactions between papain molecules and the ILs in the extraction process.

FT-IR spectroscopy is one of the classical experimental methods recognized as useful in providing information on structure features of proteins [26]. There are nine such IR

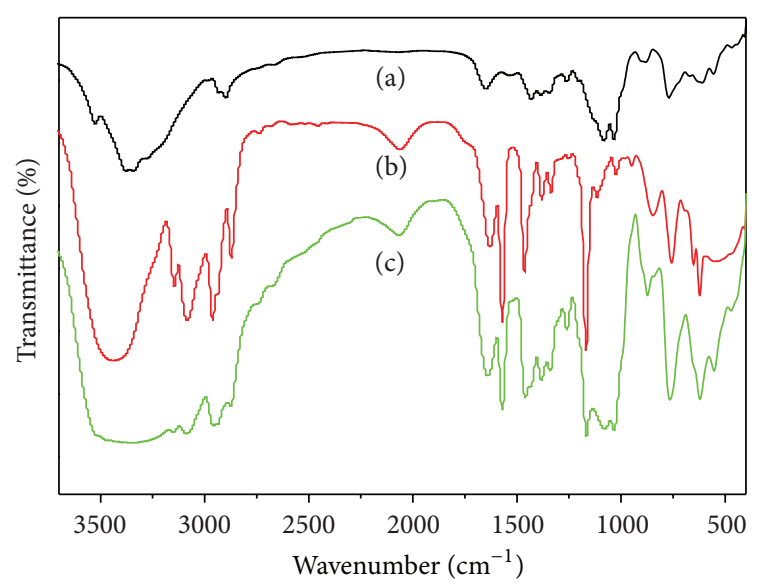

FIGURE 7: FT-IR spectra of pure papain, pure [Bmim] $\mathrm{Br}$ and papain in $[\mathrm{Bmim}] \mathrm{Br}$. (a) Pure papain; (b) pure $[\mathrm{Bmim}] \mathrm{Br}$; (c) papain in $[\mathrm{Bmim}] \mathrm{Br}$.

bands existing, which are called amide $\mathrm{A}$, amide $\mathrm{B}$, and amides I-VII [27]. Amide I band presents primarily the $\mathrm{C}=\mathrm{O}$ stretching vibration of the amide groups and exists in the region $1600-1700 \mathrm{~cm}^{-1}$, while amide II band represents the $\mathrm{C}-\mathrm{N}$ stretching vibrations and exists in the region 1480 $1575 \mathrm{~cm}^{-1}$. Of all the amide bands, it is very important to study the secondary structure of proteins by the most informative amides I and II. FT-IR spectra of the protein in ILs were obtained and compared with those of the pure protein to find out the effect of the ILs on the secondary structure of the protein. Figure 7 showed the FT-IR spectra of pure papain, pure $[\mathrm{Bmim}] \mathrm{Br}$, and papain in $[\mathrm{Bmim}] \mathrm{Br}$. As can be seen from Figure 7(c), that the amide I band (at $1639 \mathrm{~cm}^{-1}$ ) and amide II band (at $1569 \mathrm{~cm}^{-1}$ ) of the protein were identified in the spectrum of the papain in $[\mathrm{Bmim}] \mathrm{Br}$. The major IR bands of $[\mathrm{Bmim}] \mathrm{Br}$ also remained in this region after extraction. Little shift or little disappearance of the peak has been observed for the major IR bands, suggesting that the conformation of the protein was not destroyed in the IL phase. This conclusion was further confirmed by our UV-vis measurements. Consequently, we may draw the conclusion that IL-based aqueous two-phase extraction systems provide a moderate environment for protein. These systems have great potential applications in separation/purification of bioactive molecules.

\section{Conclusions}

In this paper, the $[\mathrm{Bmim}] \mathrm{X}(\mathrm{X}=\mathrm{Cl} ; \mathrm{Br})-\mathrm{K}_{2} \mathrm{HPO}_{4}$ ILATPS was applied to separate papain. The distribution of papain in the ILATPS was influenced by the amount of ILs, the concentration of $\mathrm{K}_{2} \mathrm{HPO}_{4}$, temperature, $\mathrm{pH}$, and the volume of $\mathrm{K}_{2} \mathrm{HPO}_{4}$ solution. It is shown that the extraction efficiency of the proteins is as high as $89-98 \%$ in a single step partition. The higher extraction efficiency of the proteins is achieved at the $\mathrm{pH}$ value close to their isoelectric point and under higher temperatures. The partitioning of the proteins may be predominated by the hydrophobic interactions between the 
proteins and cation of the ionic liquids in the aqueous twophase systems. The results suggest that IL-based ATPSs have the potential to offer new possibility in the separation and purification of proteins.

\section{Acknowledgments}

The authors are grateful for financial support provided by the National Nature Science Foundation of China (nos. 21166009, 21106055, and 21266007), the Natural Science Foundation of Jiangsu Province (nos. BK2011506 and BK2012697), and Doctoral Innovation Fund of Jiangsu Province (CXLX12_0667).

\section{References}

[1] M. Y. Arica and G. Bayramoğlu, "Purification of lysozyme from egg white by Reactive Blue 4 and Reactive Red 120 dye-ligands immobilised composite membranes," Process Biochemistry, vol. 40, no. 3-4, pp. 1433-1442, 2005.

[2] K. Sangeetha and T. E. Abraham, "Chemical modification of papain for use in alkaline medium," Journal of Molecular Catalysis B, vol. 38, no. 3-6, pp. 171-177, 2006.

[3] S. Nitsawang, R. Hatti-Kaul, and P. Kanasawud, "Purification of papain from Carica papaya latex: aqueous two-phase extraction versus two-step salt precipitation," Enzyme and Microbial Technology, vol. 39, no. 5, pp. 1103-1107, 2006.

[4] S. N. Su, H. L. Nie, L. M. Zhu, and T. X. Chen, "Optimization of adsorption conditions of papain on dye affinity membrane using response surface methodology," Bioresource Technology, vol. 100, no. 8, pp. 2336-2340, 2009.

[5] Y. Q. Ling, H. L. Nie, S. N. Su, C. Branford-White, and L. M. $\mathrm{Zhu}$, "Optimization of affinity partitioning conditions of papain in aqueous two-phase system using response surface methodology," Separation and Purification Technology, vol. 73, no. 3, pp. 343-348, 2010.

[6] P. Chaiwut, S. Rawdkuen, and S. Benjakul, "Extraction of protease from Calotropis procera latex by polyethylene glycolsalts biphasic system," Process Biochemistry, vol. 45, no. 7, pp. 1148-1155, 2010.

[7] M. Li, E. Su, P. You et al., "Purification and in situ immobilization of papain with aqueous two-phase system," PLoS ONE, vol. 5, no. 12, Article ID e15168, 2010.

[8] J. N. Baskir, T. A. Hatton, and U. W. Suter, "Protein partitioning in two-phase aqueous polymer systems," Biotechnology and Bioengineering, vol. 34, no. 4, pp. 541-558, 1989.

[9] R. Hatti-Kaul, "Aqueous two-phase systems. A general overview," Molecular Biotechnology, vol. 19, no. 3, pp. 269-277, 2001.

[10] Z. Li, X. Liu, Y. Pei, J. Wang, and M. He, "Design of environmentally friendly ionic liquid aqueous two-phase systems for the efficient and high activity extraction of proteins," Green Chemistry, vol. 14, no. 10, pp. 2941-2950, 2012.

[11] M. G. Freire, A. F. M. Claudio, J. M. M. Araujo et al., "Aqueous biphasic systems: a boost brought about by using ionic liquids," Chemical Society Reviews, vol. 41, no. 14, pp. 4966-4995, 2012.

[12] Q. Gai, F. Qu, T. Zhang, and Y. Zhang, "Integration of carboxyl modified magnetic particles and aqueous two-phase extraction for selective separation of proteins," Talanta, vol. 85, no. 1, pp. 304-309, 2011.

[13] H. X. Li, Z. Li, J. M. Yin et al., "Liquid-liquid extraction process of amino acids by a new amide-based functionalized ionic liquid," Green Chemistry, vol. 14, no. 6, pp. 1721-1727, 2012.
[14] F. J. Deive, A. Rodríguez, L. P. N. Rebelo, and I. M. Marrucho, "Extraction of Candida antarctica lipase A from aqueous solutions using imidazolium-based ionic liquids," Separation and Purification Technology, vol. 97, pp. 205-210, 2012.

[15] Y. Pei, L. Li, Z. Li, C. Wu, and J. Wang, "Partitioning behavior of wastewater proteins in some ionic liquids-based aqueous twophase systems," Separation Science and Technology, vol. 47, no. 2, pp. 277-283, 2012.

[16] X. Y. Zhao, F. Qu, M. Dong, F. Chen, A. Q. Luo, and J. H. Zhang, "Separation of proteins by aqueous two-phase extraction system combined with liquid chromatography," Chinese Journal of Analytical Chemistry, vol. 40, no. 1, pp. 38-42, 2012.

[17] J. A. Asenjo and B. A. Andrews, "Aqueous two-phase systems for protein separation: phase separation and applications," Journal of Chromatography A, vol. 1238, pp. 1-10, 2012.

[18] Y. Pei, Z. Li, L. Liu, and J. Wang, "Partitioning behavior of amino acids in aqueous two-phase systems formed by imidazolium ionic liquid and dipotassium hydrogen phosphate," Journal of Chromatography A, vol. 1231, pp. 2-7, 2012.

[19] M. G. Freire, C. M. S. S. Neves, I. M. Marrucho, J. N. C. Lopes, L. P. N. Rebelo, and J. A. P. Coutinho, "High-performance extraction of alkaloids using aqueous two-phase systems with ionic liquids," Green Chemistry, vol. 12, no. 10, pp. 1715-1718, 2010.

[20] U. Novak, A. Pohar, I. Plazl, and P. Žnidaršič-Plazl, "Ionic liquid-based aqueous two-phase extraction within a microchannel system," Separation and Purification Technology, vol. 97, pp. 172-178, 2012.

[21] Y. Pei, Z. Li, L. Liu, J. Wang, and H. Wang, "Selective separation of protein and saccharides by ionic liquids aqueous two-phase systems," Science China Chemistry, vol. 53, no. 7, pp. 1554-1560, 2010.

[22] Z. Li, Y. Pei, H. Wang, J. Fan, and J. Wang, "Ionic liquid-based aqueous two-phase systems and their applications in green separation processes," Trends in Analytical Chemistry, vol. 29, no. 11, pp. 1336-1346, 2010.

[23] K. E. Gutowski, G. A. Broker, H. D. Willauer et al., "Controlling the aqueous miscibility of ionic liquids: aqueous biphasic systems of water-miscible ionic liquids and water-structuring salts for recycle, metathesis, and separations," Journal of the American Chemical Society, vol. 125, no. 22, pp. 6632-6633, 2003.

[24] Y. C. Pei, J. J. Wang, L. Liu, K. Wu, and Y. Zhao, "Liquid-liquid equilibria of aqueous biphasic systems containing selected imidazolium ionic liquids and salts," Journal of Chemical and Engineering Data, vol. 52, no. 5, pp. 2026-2031, 2007.

[25] M. Lu, P. Å. Albertsson, G. Johansson, and F. Tjerneld, "Partitioning of proteins and thylakoid membrane vesicles in aqueous two-phase systems with hydrophobically modified dextran," Journal of Chromatography A, vol. 668, no. 1, pp. 215-228, 1994.

[26] A. Barth, "The infrared absorption of amino acid side chains," Progress in Biophysics and Molecular Biology, vol. 74, no. 3-5, pp. 141-173, 2000.

[27] Y. Pei, J. Wang, K. Wu, X. Xuan, and X. Lu, "Ionic liquid-based aqueous two-phase extraction of selected proteins," Separation and Purification Technology, vol. 64, no. 3, pp. 288-295, 2009. 

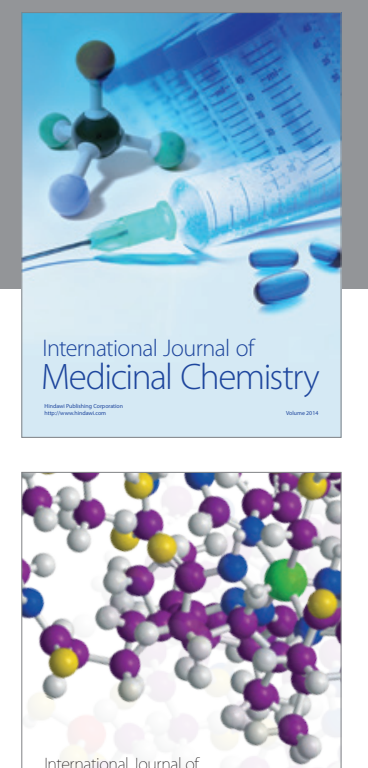

\section{Carbohydrate} Chemistry

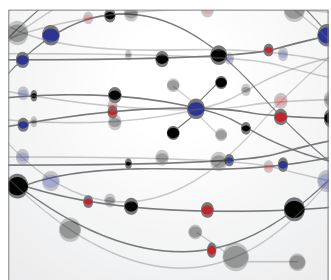

The Scientific World Journal
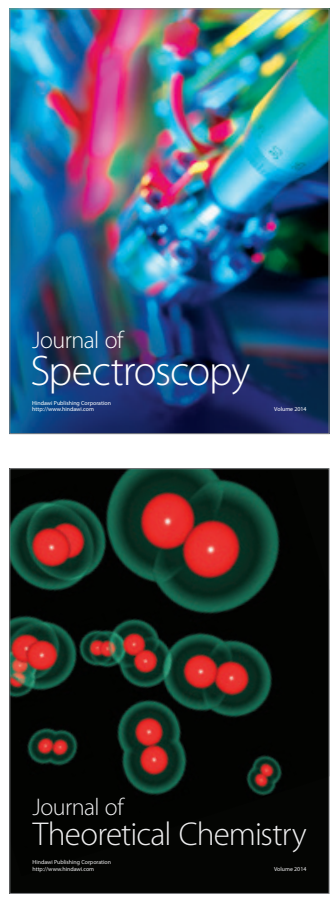
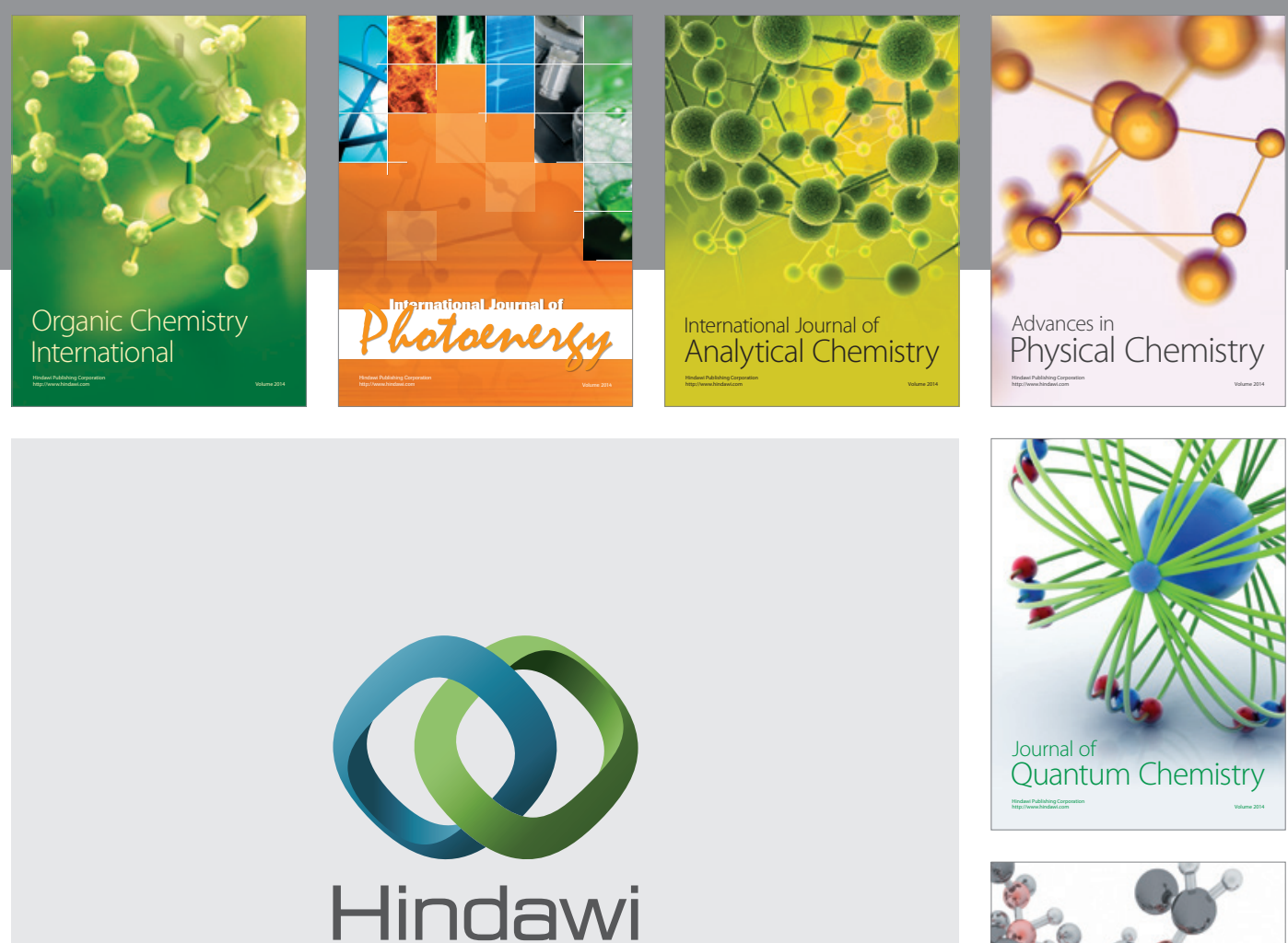

Submit your manuscripts at

http://www.hindawi.com

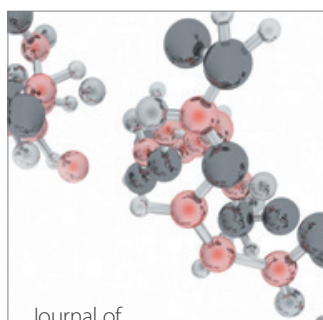

Analytical Methods

in Chemistry

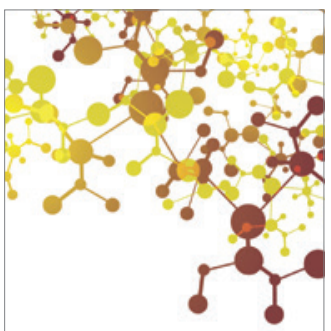

Journal of

Applied Chemistry

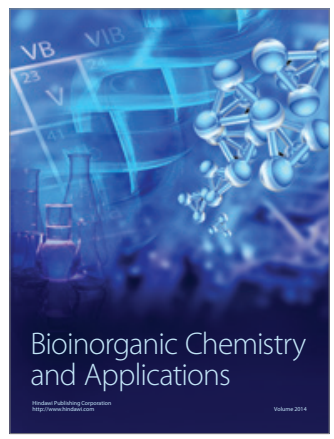

Inorganic Chemistry
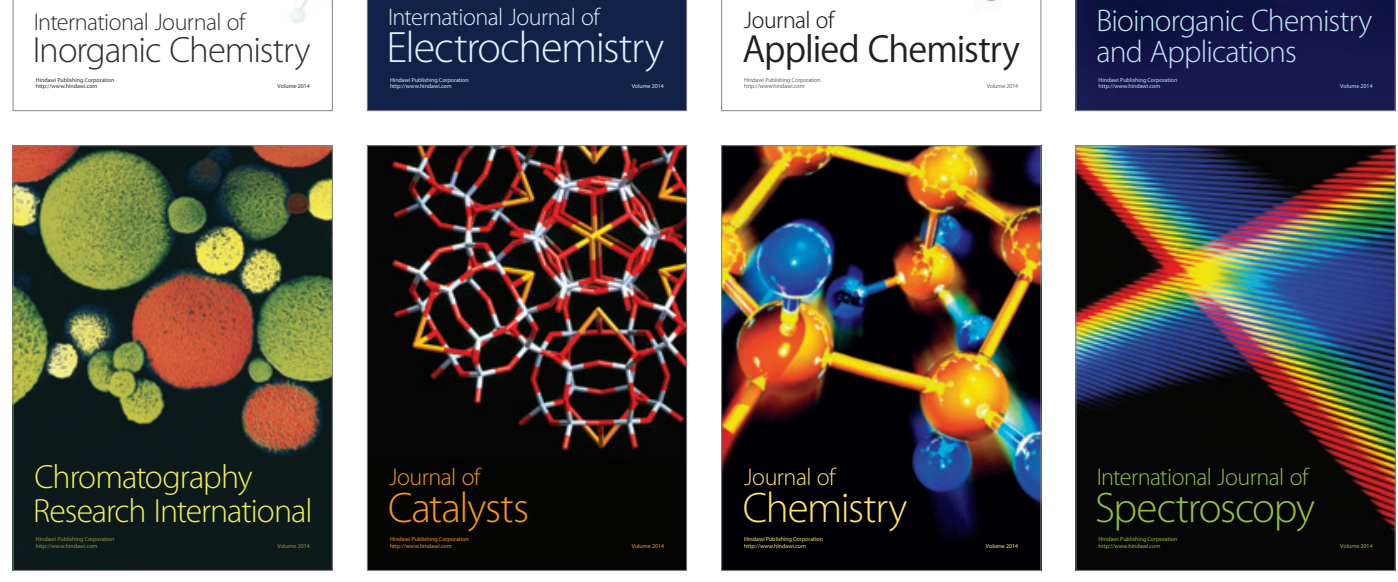